\title{
ELEGIE EN SUMPOSION
}

\author{
W J Henderson (Randse Afrikaanse Universiteit)
}

\section{$1 \quad$ Inleiding}

Die onlangse simposia oor die sumposion (Oxford 1984 en Ontario 1988) het opnuut die aandag gevestig op die belangrike rol wat hierdie instelling in die Griekse stadstaat gespeel het. (Die referate van die Oxford-simposium is gepubliseer (Murray 1990), dié van die Ontario-simposium (red. W J Slater) nog nie.) Daar is ook opnuut deur Bowie (1990:221-229) en Rösler (1990:230-227) betoog dat die sumposion die belangrikste plek was vir die voordrag, nie net van die liriek nie, maar ook van die elegie. Veral Bowie het al in 'n vroeër artikel (1986:13-35) 'n sterk saak ten opsigte van die vroeë Griekse elegie uitgemaak. Gedetailleerde analise van bepaalde gedigte, soos deur Latacz by geleentheid van die Ontario-simposium bepleit is (1990:244-254), het minder aandag geniet. Die huidige bydrae bou voort op 'n vroeër artikel (Henderson 1989:174-180), en bespreek latere simpotiese elegieë om hulle aard en gehalte aan te toon, asook om hulle verband met die simposium uit te lig.

\section{Xenophanes van Kolophon}

Xenophanes van Kolophon (c.565-c.470 vC) se eerste elegie is telkemale al aangehaal in besprekings rondom die sumposion, omdat dit soveel eksplisiete besonderhede van die sumposion verskaf.

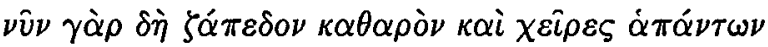

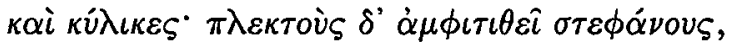

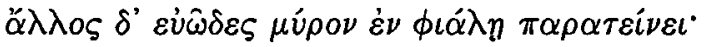

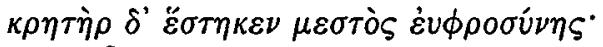

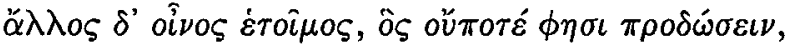

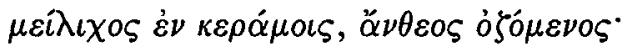

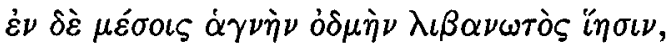

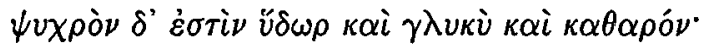

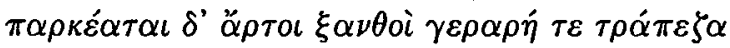

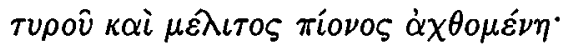

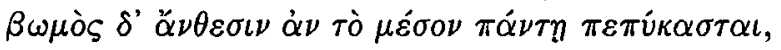

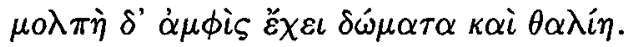

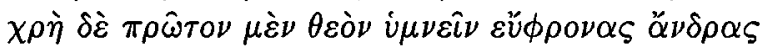

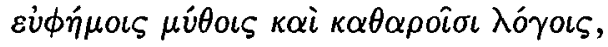

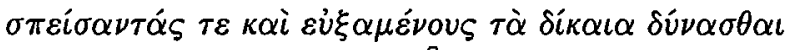

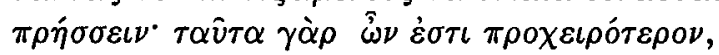

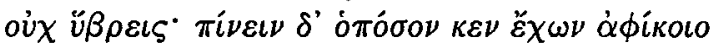




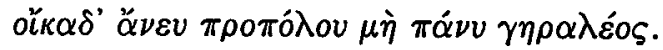

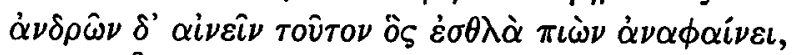

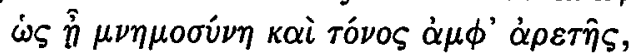

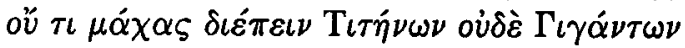

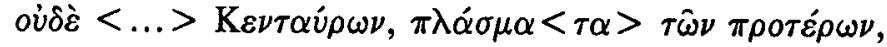

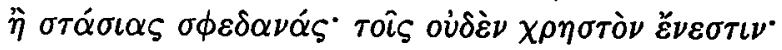

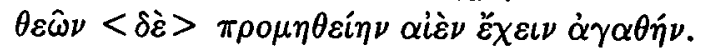

Wel, nou is die vloer inderdaad skoon, ook almal se hande

én die bekers. Een plaas gevlegte kranse om ons hoofde,

' $n$ ander bied ons welriekende olie in 'n bakkie,

en die mengkruik staan vol joligheid.

Ander wyn staan gereed, wat sê dat daar genoeg gaan wees, gemoedelik in kruike, met die geur van 'n blom.

In ons midde gee wierook 'n skoon reuk af

en die water is koud en soet en rein.

Daar staan gereed goudbruin brode en 'n majestueuse tafel gelaai met kaas en ryk heuning.

In die middel is ' $n$ altaar oral met blomme versier

en musiek vul die kamer rondom, en feestelikheid.

Eers moet vrolike manne god besing

met eerbiedige verhale en reine woorde,

na hul gepleng en gebid het om die regte dinge te kan

doen-want dit is immers die belangrikste,

en geen oormaat: om net soveel te drink dat jy huistoe

kan keer sonder 'n slaaf-behalwe as jy heeltemal oud is.

Maar van manne moet ons hóm prys wat tydens die gedrink

edel temas sing, soos sy geheue en strewe na deug

toelaat, en nie uitwei oor die Titane, Reuse of [...] Kentoure

se gevegte nie-versinsels van vroeër digters-

of oor hewige opstande-daar's g'n nut dáárin nie.

Maar 'n mens moet altyd 'n goeie ontsag vir die gode hê.

(fr. 1 West, Edmonds)

Teen Xenophanes se tyd het die simposium sy prominente rol in die samelewing grotendeels verloor. Hy skep dus 'n ideale simposium met 'n sterk religieusfilosofiese element (vgl. Barkhuizen in Barkhuizen et al. 1986:142-145; Murray 1990a:150; Lissarrague 1990:206; Rösler 1990:230-231). Tog baseer hy sy beskrywing van die verloop en elemente van die Griekse sumposion op kennis van werklike simposia. Bielohlawek (1940:21) beskou dit as "durch ihre Ethik und den eigenartigen Zauber ihrer Konzeption die edelste und dichterisch stärkste Symposionsparänese."

Eers is daar die voorbereidings: die vloer word skoongemaak, die drinkbekers gewas; water word verskaf vir die gaste om hulle hande te was; gevlegte 
blommekranse word om die slape van die gaste geplaas, en gegeurde olyfolie word in 'n kruik rondgedra vir die gaste se gebruik op hulle hande, hare en gesig; 'n groot mengvat staan gereed met die mengsel van wyn en water, en ekstra voorrade is byderhand; wierook brand in die vertrek; brood, kaas en heuning staan op die tafel; in die middel van die tafel (so lyk dit) is 'n klein altaartjie met blomme versier; en musiek klink oral op.

'n Mens merk die verskeidenheid van kleure (blomme, goudbruin brode, goue heuning, die kleure van wyn, en die helderheid van water), geure vir smaak en reuk (gegeurde olie, geurige wyn, wierook en die voedsel), klanke (musiek en vrolikheid), en selfs teksture (water en olie vir die hande). Op hierdie wyse word al vyf sintuie geprikkel, en die effek van $\chi \alpha$ á $\rho \varsigma$ verkry. Dan, uit die gegewens oor die skoonmaak van die vertrek, en die teenwoordigheid van die wyn in voldoende hoeveelhede, asook die oorgang in die res van die gedig tot sang, kan ons aflei dat hierdie die simpotiese (dit wil sê drink- en sing-)gedeelte van die banket is, ná die eetgedeelte $(\delta \varepsilon i \pi \nu 0 \nu)$. Nog meer: sekere elemente in die beskrywing suggereer 'n religieus-filosofiese belangstelling van die digter: die woord $\kappa \alpha \theta \alpha \rho o ́ \nu$, "skoon", "rein", word gebruik van die vloer (reël 1), die water (reël. 8) en van die liedere (reël 14). Rituele reiniging word daarmee gesuggereer, versterk deur die teenwoordigheid van wierook en 'n altaar (Bielohlawek 1940:22). Of die altaar in die middel van die vertrek of van die tafel staan, dit is heel ongewoon by tradisionele simposia. Verskeie oplossings is al voorgestel: dis 'n improvisasie, 'n altaar by ' $n$ heiligdom, of ' $n$ simboliese altaar (kyk Barkhuizen in Barkhuizen et al. 1986:144). 'n Bevredigende oplossing lyk onmoontlik, maar dit is duidelik dat die altaar die fokuspunt van die banket is. Von der Mühll (1983:11-12) het ook op die sakrale betekenis van die simposium gewys en dit aan inisiasie in die nuwe groep gekoppel.

Vervolgens word die aktiwiteite van die simposium beskryf: 'n plengoffer en gebed om reg te kan optree; 'n lied met eerbiedige verhale en in reine woorde tot 'n god; matigheid, sodat 'n slaaf se hulp, behalwe in die geval van 'n ou man, nie nodig sal wees om tuis te kom nie. "Auch hier herrscht die Charis," verklaar Bielohlawek (1940:22).

Die plengoffer en gebed bevestig die religieuse wese van die simposium. Normaalweg is die gebed tot Zeus Sôtêr gerig en was dit vir gesondheid en voorspoed. Hier maan die digter sy gaste om te bid vir die vermoë om regverdig te kan optree. Dit gee 'n sterker etiese inslag (Bielohlawek 1940:22). Ook in die geval van die lied tot ' $\mathrm{n}$ god is dit dalk iets eie aan Xenophanes. Die betrokke lied was die $\pi \alpha \iota \alpha \dot{\nu}$, wat oorspronklik tot Apollo, maar toenemend ook tot ander gode gerig is. By 'n sumposion was die aangewese god dan Bakchos of Dionusos, god van wyn. Hier lyk dit egter of Xenophanes net na een god vir sowel die plengoffer en gebed as die paian verwys. Tot hierdie god moet net mites wat respek betoon en in gesuiwerde taal verwoord is, en nie die gewone, tradisionele mitiese vertellinge oor die wel en weë van die gode nie, gerig word. Hierdie siening sou strook met stellings in antieke testimonia dat Xenophanes die tradisionele opvattinge oor die 
gode aangeval het (bv. Diog. Laert. 9.18; Aristot. Rhet. 2.23.1399b6), en 'n monoteïs was (Diog. Laert. 9.19; Xen. fr.23 Diels-Kranz).

Die maning tot matige gebruik van wyn is weer niks nuuts nie: die Griekse simposium was ' $n$ beheersde, taamlik intellektuele geleentheid, waar die wyn altyd met tweekeer of driekeer meer water gemeng was (Hdt. 6.84; Plato Leg. 637e; Pellizer 1990:178-179). Xenophanes verwys in 'n ander fragment (4 West, Edmonds) eksplisiet na die vermenging van die wyn:

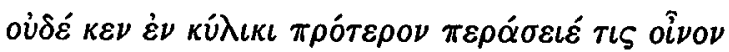

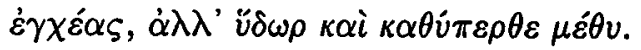

Ook sou ' $n$ mens nie in die beker eers die wyn skink as hy dit meng, maar eers water en dan bo-op die drank.

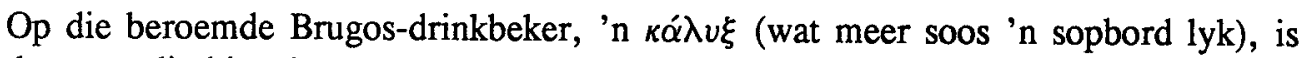
daar aan die binnekant 'n voorstelling van 'n jongman wat opbring terwyl 'n meisie hom troos (afbeelding in Arias 1962: foto 138, plaat XXXIII). Tydens 'n simposium waar so 'n beker gebruik sou word, sou die wyn die voorstelling weggesteek het totdat 'n persoon die beker geledig het. Die oomblik as die beker leeg is, sien die drinker die voorstelling voor sy oë. Dit wat die jongman in die beker dus oorkom, word as ' $n$ waarskuwing vir die drinker voorgehou-'n Griekse geval van matigheid voor oë! Xenophanes voeg egter ' $n$ rasionele-en komiese-addendum by: 'n mens moet nie soveel drink dat jy nie sonder 'n slaaf se hulp (behalwe as jy oud is) huis toe kan loop nie.

In die laaste gedeelte van die gedig (reëls 19-24) kom die persoonlike advies van die digter weer na vore, hierdie keer in verband met die temas van die liedere wat gesing gaan word. Hy beveel liedere met 'n edel tema by die gaste aan, liedere wat onthou kan word en wat "deug" bevorder. Die woord $\dot{\alpha} \rho \varepsilon \tau \eta^{\prime}$ omsluit 'n hele spektrum aristokratiese waardes en strewes, en veral die fisieke vermoëns wat op die slagveld, jagtog en atletiekbaan na vore tree. Die vertaling is iets soos "merietes", "geërfde kwaliteite", "praktiese vaardighede", iets meer spesifiek en konkreet as ons morele "deug", iets wat in elk geval beperk is tot manlike, meestal aristokratiese vermoëns. Tog skemer iets deur van 'n morele byklank in Xenophanes se siening. Hy verwerp die tradisionele epiese temas wat handel oor die gode se gevegte met die Titane, Reuse en Kentoure, asook oor gevegte, twis op die menslike vlak, in die stadstaat. Dít was versinsels van vorige digters. Die liedere wat hy vereis, moet opheffend, bevorderend vir die sedes wees, en dan veral ontsag vir die gode betoon (vgl. Barkhuizen in Barkhuizen et al. 1986:146-148). Hierdie doel is in lyn met die ideaal van die vroeër simposium: om vrede en harmonie binne die groep te bevorder (vgl. Schmitt-Pantel 1990:23).

Interessant is ook die gebruik van die lied op twee vlakke: (1) lof aan die god deur middel van 'n vertelling van die $\mu \hat{v} \theta o \iota$, dit wil sê verhale in versvorm oor die god se geboorte, mag, optrede, en dies meer; en (2) die vermaak en opheffing van die gaste. Hiervoor was 'n goeie digter noodsaaklik: sy geheue, sy toewyding aan, 
sy vertoon van die edele en vermyding van verhale van mitiese ongediertes en temas wat nie respek vir die gode betoon nie, of van temas van stryd en twis-nutteloos in Xenophanes se oë omdat hy veral die Homeriese en Hesiodiese gode-opvatting as antropomorfies beskou het-het die sumposion sinvol gemaak.

Dat Xenophanes se gedig self tydens so 'n geleentheid soos in die gedig beskryf, voorgedra is, word nie eksplisiet gesê nie. Tog is daar etlike aanduidings dat dit wel die geval was. Die beste plek om oor die vorm, verloop, inhoud en funksie van die simposium te besin is juis gedurende so 'n simposium; enige ander plek sou sinneloos wees. Xenophanes onderskei verder hier ten minste drie soorte poësie: (1) die himne aan die godheid (wat 'n liriekvorm was); (2) gedigte met verhale van die stryd tussen die Olimpiese gode en die Titane en Gigantes, of tussen verskeie volkere en die Kentoure: hier word na Homeriese en Hesiodiese (dit wil sê heksametriese) heldepoësie verwys; en (3) gedigte oor twiste, wat een van die liriekvorms was, maar ook 'n gereelde tema in die skolia (drinkliedere). Die digter beveel gedigte aan wat edele temas bevat en wat die $\dot{\alpha} \rho \varepsilon \tau \dot{\eta}$ en $\delta i \kappa \eta$ (geregtigheid) van die gemeenskap bevorder. Hier sou epiek, liriek en elegie ewegoed kwalifiseer. Xenophanes sluit egter die Homeriese epiek eksplisiet uit as teenstrydig met sy hele filosofies-religieuse opvatting; dit was egter ook lank nie meer 'n simpotiese digvorm nie. Wat oorbly is die liriek en ander simpotiese digvorms-waaronder ook die elegie, soos deur Xenophanes ook geskryf.

Daar is ook getuienis buite die gedig. Volgens Diogenes Laertios (9.18) het Xenophanes openbare voordragte van sy gedigte gegee. Dit sou natuurlik na 'n vertoning in die $\alpha \gamma o \rho \alpha ́$ kon verwys. Plutarchos (De vitioso pudore 5) gebruik egter as analoog 'n episode waar Xenophanes tydens 'n banket geweier het om Lasos van Hermionê se uitdaging tot 'n spel met dobbelstene te aanvaar. 'n Ander testimonium verdien kritiese aandag. Aristoteles (Rhet. 1400b5) vertel dat die inwoners van Elea Xenophanes gevra het of hulle ter ere van Leukotheia ("Wit godin", 'n seegodin) offers moes bring en klaagliedere sing, of nie. Hy sou toe "aan die Eleërs" geantwoord het dat, as hulle haar as 'n godheid beskou, hulle haar nie klaagliedere moes toesing nie; en as hulle haar as sterflik beskou, hulle geen offers aan haar moes bring nie. In hierdie verhaal is die kommunikasieproses soos volg: eerstens, die Eleërs stel aan Xenophanes hulle vraag; daarop volg sy antwoord. Maar wat is die milieu, die lokaliteit van so 'n proses? Digters het gereeld tydens 'n banket, voor 'n geselekteerde groep vriende, namens en tot die gemeenskap as geheel gespreek. "Die Eleërs" is dus hier nie noodwendig die hele burgerbevolking tydens 'n openbare vergadering van die volk in die $\dot{\alpha} \gamma o \rho \alpha ́$ nie, of 'n gesantskap na die digterfilosoof se huis nie. Hulle is ewe moontlik 'n verteenwoordigende groep vriende tydens 'n sumposion. Die gevatheid van Xenophanes se antwoord (Aristoteles se bondige Grieks behou nog iets van die skerp fokus en antitese van die elegiese vers), en die "eenheid" van die episode (vraag en antwoord tydens dieselfde geleentheid) dui op 'n simpotiese milieu. 


\section{Theognis van Megara}

Die elegiese poësie van Theognis van Mégara, Sicilië ( $6 \mathrm{e}$ eeu $v C$ ), en die versameling wat as die Theognidea $(6 \mathrm{e}-5 \mathrm{e}$ eeu $\mathrm{vC})$ bekend staan, is in tema, stemming en funksie simpoties (kyk Bowie 1986:15; West 1990:272-276). Afgesien van tipies simpotiese temas soos die sosio-politieke probleme en kwale van die stadstaat (byvoorbeeld geld-gebaseerde teenoor aristokratiese magsuitoefening), vriendskap, moraliteit ( $\gamma \nu \omega \dot{\mu} \mu \alpha \iota$ oor gedrag, die houding teenoor die gode, deug teenoor rykdom, die menslike lewe en lotsbestemming, hoogmoed, carpe diem), die $\kappa \hat{\omega} \mu \circ \varsigma$, die poësie (sang, fluit- en lierspel), en die liefde (veral pederastie wat die hele "boek II", reëls 1231-1388, in beslag neem), is daar die direkte verwysings na of beskrywings van die banket of elemente daarvan. Veral die drink van wyn figureer prominent: die voordele en nadele, die noodsaaklikheid van matigheid (reëls $211-212$, 237-254, 413-414, 467-496, 497-498, 499-502, 503-508, 509-510, $627-628,841-844,873-876,879-884,939-942$, 971-972, 989-990, 1039-1040, 1047-1048, 1129-1132, 1207-1208).

Die opvoedkundige funksie van die sumposion word eksplisiet gestel in reëls 563-566:

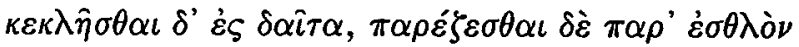
$\ddot{\alpha} \nu \delta \rho \alpha \chi \rho \varepsilon \dot{\omega} \nu \sigma o \phi i \eta \eta \pi \hat{\alpha} \sigma \alpha \nu \dot{\varepsilon} \pi \iota \sigma \tau \alpha \dot{\alpha} \mu \varepsilon \nu o \nu$.

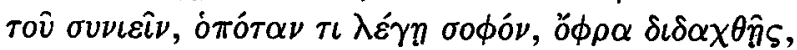

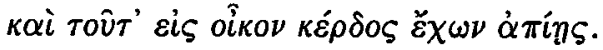

Om genooi te wees na 'n feesmaal, om te sit langs 'n edelman wat alle kennis in pag het, is goed en wel;

hou hom dop as hy wysheid kwytraak, sodat jy kan leer en met hierdie wins huistoe kan keer.

Uit die testimonia rondom die Theognidea blyk dit dat hierdie gedigte, veral weens hulle etiese inslag, 'n wyer gehoor as dié van die feesmaal bereik het, en by ander geleenthede as die feesmaal gekommunikeer is. Een van hierdie testimonia kom van Plato waar hy dit oor die rol van die poësie in die opvoeding van die jeug het (Leg. 810e). Die passasie werp ook lig op die elegie in die besonder: Plato verwys na heksametriese vers, en na vers met 'n ernstige doel ( $\dot{\varepsilon} \pi \dot{i} \sigma \pi o v \delta \dot{\eta} \nu$ ) teenoor die jambiese vers wat oor die algemeen meer skertsend en lagwekkend was ( $\dot{\varepsilon} \pi i$ $\gamma \varepsilon \lambda \omega \tau \alpha)$. Maar dit betrek ook indirek dalk die etiese vers van die Theognidea. "Ander mense," sê Plato, "selekteer opsommings van die geheel en versamel sekere passasies wat in sigself ' $n$ geheel vorm, en sê dan dat hulle in die geheue gevestig moet word as enige kind van ons edel en wys wil word uit ervaring en kennis" (oi $\delta \dot{\varepsilon}$

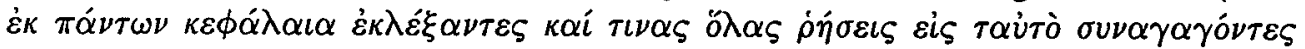

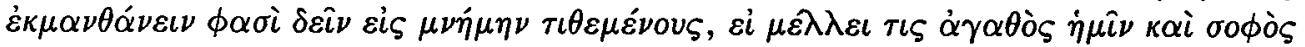

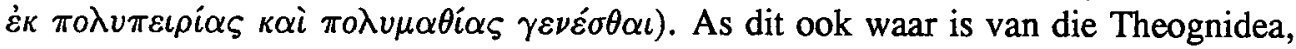
dan werp Plato lig op die "publikasie" daarvan. Die Theognidea soos ons dit nou 
besit, is waarskynlik juis so 'n bloemlesing wat ná die tyd van Aristoteles ontstaan het. Diogenes Laertios, in die $3 \mathrm{e}$ eeu $\mathrm{nC}$, ken tien boekrolle daarvan. Plato kon natuurlik nie na die Theognidea self verwys het nie-alhoewel hy meermale na Theognis self verwys (Leg. 630a; Meno 95cde)-maar na 'n tipe versameling. Sulke bloemlesings of seleksies wat vir kinders of jongmense bedoel was, is tog sekerlik nie via die simposium oorgedra nie. Die waarskynlikste vorm van oordrag sou dan die hardop voorlees uit 'n geskrewe kopie in 'n "skoolsituasie" gewees het.

Die ander relevante testimonia bevestig die strekking van hierdie argument. Aristoteles haal reëls 255-256 van Theognis aan met die verduideliking dat die teks by die ingang van die tempel van Leto by Delphi opgeskryf was (Eth. Eud. 1214a1; Eth. Nic. 1099a25; Stob. 103.8). Dio Chrusostomos meen (2.18) dat gedigte wat raad en aanmoediging gee, soos dié van byvoorbeeld Theognis, "demoties", dit wil sê "volks", is, teenoor ander poësie wat vir konings bedoel is, soos drinkliedere, liefdesliedere, prysliedere, klaagliedere en hekelverse-kortom, simpotiese verse. As ons hierdie uitspraak op sigwaarde aanvaar, lyk dit of hy Theognis se poësie in die kader van die wye publiek, en buite die kader van die banket, wil plaas. Dit is veilig om te aanvaar dat teen Chrusostomos se tyd (1e eeu $\mathrm{nC}$ ), die Theognidea ver buite die beperkte milieu van die feesmaal sy gehoor gehad het. Hierdie tendens sou ook korreleer met die toenemende gebruik van die geskrewe teks in die ontginning en verspreiding van kennis vanaf die einde van die $5 e$ eeu, en veral ná Plato.

\title{
4 Ion van Chios
}

Onder die behoue elegiese fragmente van Ion van Chios (c.480-422 vC) is twee wat die simposium, en veral sy beskermende god, Dionusos, en die vrug van die wingerd besing.

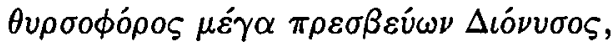 \\ [ \\ $\alpha \tilde{\tau} \tau \eta \dot{\alpha} \rho \pi \rho o ́ \phi \alpha \sigma \iota \varsigma \pi \alpha \nu \tau o \delta \alpha \pi \hat{\omega} \nu \lambda{ }^{\prime} \gamma \dot{i} \omega \nu$, \\ $\alpha \ddot{\imath} \tau \varepsilon \Pi \alpha \nu \varepsilon \lambda \lambda \dot{\eta} \nu \omega \nu \dot{\alpha} \gamma o \rho \alpha \grave{i} \theta \alpha \lambda i \alpha \iota \tau \varepsilon \dot{\alpha} \nu \dot{\alpha} \kappa \tau \omega \nu$,

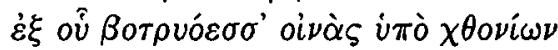

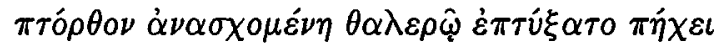 \\ $\alpha i \theta \dot{\varepsilon} \rho \circ \varsigma^{*} \dot{o} \phi \theta \alpha \lambda \mu \hat{\omega} \nu \delta^{\prime} \dot{\varepsilon} \xi \varepsilon \dot{\varepsilon} \theta 0 \rho \circ \nu \pi u \kappa \iota \nu \circ \grave{\imath}$

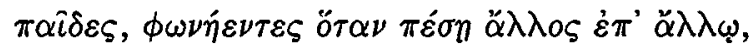

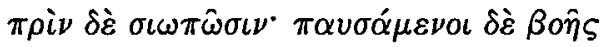

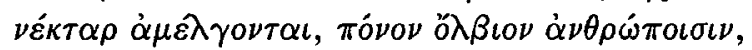

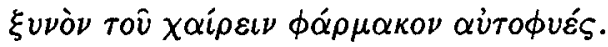

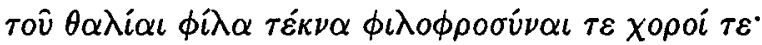

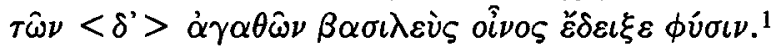

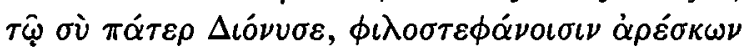


$\dot{\alpha} \nu \delta \rho \alpha ́ \sigma l \nu, \varepsilon \dot{v} \theta \dot{v} \mu \omega \nu \sigma \nu \mu \pi \sigma \sigma i \omega \nu \pi \rho \dot{\tau} \tau \alpha \nu l$, $\chi \alpha \hat{\imath} \rho \varepsilon^{\prime} \delta i \delta o v \delta^{\prime} \alpha i \hat{\omega} \nu \alpha \kappa \alpha \lambda \hat{\omega} \nu$ ह่ $\pi \iota \dot{\eta} \rho \alpha \nu \varepsilon$ है $\rho \gamma \omega \nu$

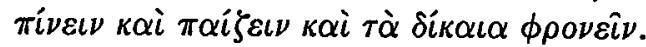

Thursos-draende, hooggeëerde Dionusos, [

want dit is die tema van veelvoudige stories:

die vergaderings van alle Grieke en feeste van heersers, sedert die trostende wingerd vanuit die aarde

sy loot opgelig en met geil arm die hemel

toegevou het, en van sy oë saamgedronge kinders

voortgespruit het, wat raas as die een op die ander val, maar tot dan swyg; en as hul ophou huil, word hul nektar gemelk, heerlike taak vir mense,

'n algemene, self-gekweekte raat vir genot.

Hiervan is die dierbare kinders feeste, geselskap en danse;

en koning wyn wys die ware wese van die goeie mense.

Aan sy vader, u Dionusos, bemin deur manne wat blommekranse

liefhet, arbiter van vrolike sumposia,

groete: gee my lang lewe, aanhelper van mooi dade,

om te drink en "speel" en geregtigheid te bedink.

(fr. 26 West, 1 Edmonds)

Die verwysings na elemente van die sumposion is duidelik genoeg: Dionusos met sy

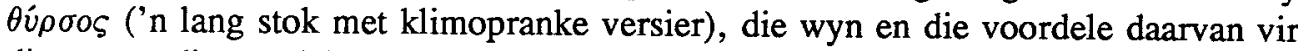
die mens, die geselskap van vriende, die danse (of hier meer spesifiek die $\kappa \hat{\omega} \mu o \iota$ ), blommekranse, drink en "speel" ( $\pi \alpha i \zeta \varepsilon \iota \nu$ beteken eintlik "met seuns speel", 'n verwysing na pederastie). Ewe duidelik is Ion se bewustheid van die lang tradisie van die banket (2 e.v.). Twee ander aspekte moet egter uitgelig word.

Eerstens is daar die verwysing na die "ware wese van die goeie mense" (12) en die bede aan Dionusos om 'n lang lewe te skenk onder andere "om geregtigheid te bedink" (16). Die digter dink hier kennelik aan die morele, opvoedkundige funksie van die sumposion, die geleentheid waar die gemeenskaplike etiese en sosio-politieke ideale van die aristokrasie besing, bespreek, voorgedra en aan die jongeres oorgedra is. "Die goeie mense" ( $\dot{\alpha} \gamma \alpha \theta 0 \hat{\imath})$ is die adel, en die wyn help om húlle $\phi \dot{v} \sigma \iota \varsigma$ tot

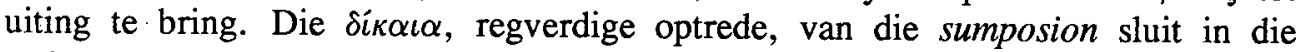
gedrag en optrede van die $\dot{\alpha} \gamma \alpha \theta$ oi onderling, tydens en buite die sumposion.

In die tweede plek is daar die frase "die tema van veelvoudige stories" (2). Die uitleg hiervan is moeilik. Die woord $\lambda o \gamma i \omega \nu$ kan die genitief meervoud wees van

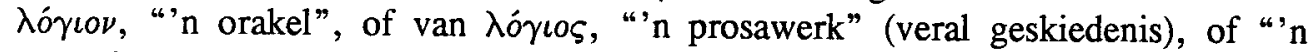
prosaskrywer" (veral 'n historikus). Voldoende konteks ontbreek, en daar moet gekyk word na die gebruik van die woord elders in Grieks. Die woord kom net hier voor in die oorgelewerde jambiese en elegiese vers, maar Pindaros tref 'n

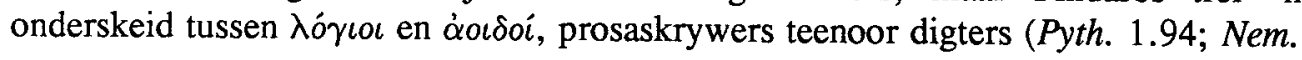


$6.45)$; en Herodotos $(1.1 ; 2.3 ; 4.46)$ en Polubios $(6.45 .1 ; 38.6 .1)$ gebruik $\lambda o ́ \gamma \iota \varsigma$ van geskiedskrywing. Indien prosawerke of prosaskrywers (veral skrywers van annale of geskiedenis) hier bedoel word, het ons 'n gedig waarin die digter na die prosaliteratuur verwys, en dus na 'n lesende publiek, buite die simposium.

Die tweede elegie van Ion het 'n dergelike tema.

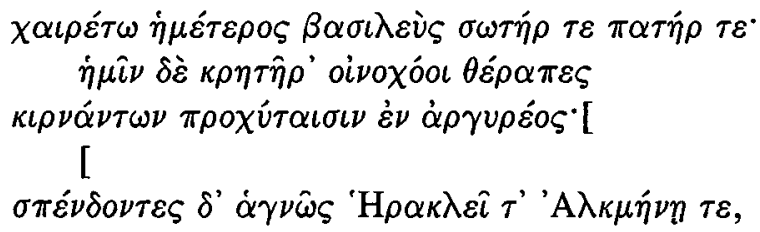

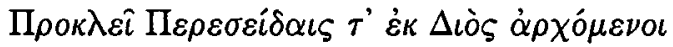

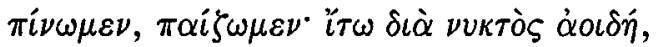

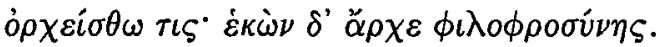

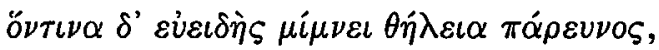

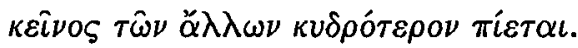

Wees gegroet, ons koning en redder en vader, en laat die wynkelners vir ons bekers

meng in drinkbekers van silwer; [

Terwyl ons 'n reine plengoffer maak aan Herakles en Alkmena

en Prokles en die kinders van Perseus, maar by Zeus begin, laat ons drink en "speel", laat sang deur die nag opklink, laat iemand dans, en begin met graagte die lekker geselskap;

en as 'n mooi vrou as bedmaat vir iemand wag, laat hom trotser as die ander drink!

(fr. 27 West, 2 Edmonds)

Elemente van die sumposion is eksplisiet: lof aan Dionusos, die meng en bediening van wyn, plengoffers aan Zeus en ander figure, die homoseksuele "speel" met die jong kelners, sang, dans, geselskap, en die heteroseksuele afloop ná die $\kappa \hat{\omega} \mu \circ \varsigma$. Die mitologiese figure wat saam met Zeus in die heildronk vereer word, is aan mekaar verwant: Herakles was die seun van Alkmena, wat weer een van die Perseidai (nasate van Perseus) was; en Prokles was een van Herakles se nakomelinge. Hierdie figure kom voor in heldekultusse (Alkmena: Pind. Nem. 10.15; Paus. 1.19.3; Apollod. 2.4.5; Stoll 1965; Herakles: Pötscher 1967; Prokles: Athen. 10.463b; Paus. 3.16.6; Höfer 1965), asook as karakters in tragedies (die Alkmene van Ion self en van Aischulos, die Herakleidai en Herakles van Euripides). Hulle teenwoordigheid hier kan dus in terme van een of albei van hierdie twee gegewens, kultiese en/of literêre verwysing, verklaar word. Ion was ook tragediedigter, en dit is moontlik dat hy hierdie karakters uit hulle "normale" genre oorgeplaas het in sy simpotiese elegie om dit 'n ander dimensie te gee. Dit is egter spekulasie. 


\section{Dionusios Chalkos}

'n Sterk en eksplisiete simpotiese inslag is ook in die elegieë van Dionusios Chalkos van Athene (middel-5e eeu vC) te vinde. Hy was digter en redenaar (Athen. 15.669d) en leier van die stigters van die kolonie Thurii in Sicilië. Fragment 2 is 'n uitnodiging wat tydens ' $n$ feesmaal te pas kom as die drinkfase bereik word:

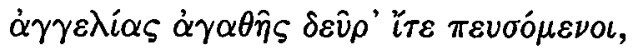

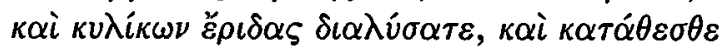

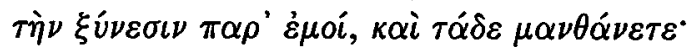

$$
\begin{aligned}
& \text { Toe kom, en luister na die goeie nuus, } \\
& \text { en laat vaar die twis wat uit bekers kom, en vergaar } \\
& \text { goeie oordeel van my, en leer die volgende: }
\end{aligned}
$$

Die didaktiese toon en doel van die verlore gedig waarvan hierdie die aanhef was, is hier helder genoeg. Wat ook tot ons begrip bydra, is die aanbeveling van matigheid en 'n rustige, argumentvrye atmosfeer waarbinne die didaktiese (en hedonistiese) funksie van die banket en sy gedigte sigself kan voltrek. Hierdie "vrede" is 'n element wat ook in Solon se fr. 4.9-10 West voorkom as hy die adel van sy tyd vir hulle oordadige bankette kritiseer. Die matigheidsideaal is konstant in die Griekse simposium.

Die кó $\tau \alpha \beta \beta \varsigma$, 'n speletjie wat tydens die drinkgedeelte van die feesmaal gespeel is en veral 'n Siciliaanse gebruik was (Kritias fr. B2 West, 1 Edmonds; Edmonds 1968:1.454 n.1), word in 'n variante vorm in frr. 3 en 4 West, Edmonds beskryf:

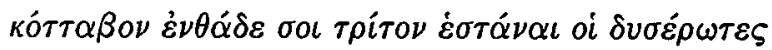

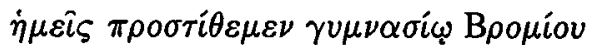
$\kappa \dot{\omega} \rho v \kappa o \nu$. oi $\delta \dot{\varepsilon} \pi \alpha \rho o ́ \nu \tau \varepsilon \varsigma \dot{\varepsilon} \nu \varepsilon i \rho \varepsilon \tau \varepsilon \chi \varepsilon \varepsilon i \rho \alpha \varsigma \ddot{\alpha} \pi \alpha \nu \tau \varepsilon \varsigma$

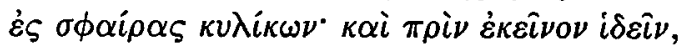

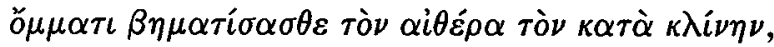

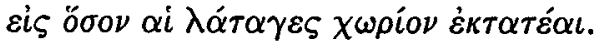

'n Derde kottabos skryf ons verliefdes nou vir jou voor om plek in te neem in die skool van Dionusos:

die "leersak". Julle hier teenwoordig ryg jul hande almal in die ore van die bekers; en vóór 'n ander sien, meet met jou oë die afstand af, al langs die eetbank, tot waar die wyndruppels heen moet trek. 


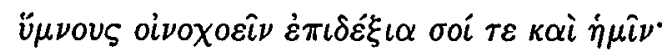

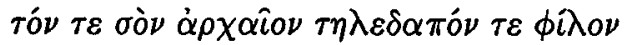

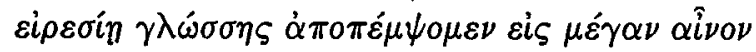

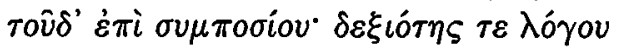

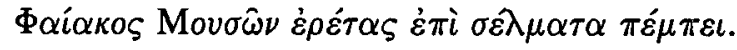

Om himnes uit te skink in beurte vir $\mathrm{u}$ en ons;

en ons sal $u$ ou vriend wat van ver gekom het,

met roeispane van die tong wegstuur tot groot lof

by hierdie feesmaal; vaardigheid van die woord

stuur Phaiakiese roeiers na die roeibanke van die Muses.

Etlike woorde wys op die sumposion as die geleentheid vir die "publikasie" van die elegie: in fr. 3, die aanwysings vir 'n derde vorm van die кó $\tau \tau \alpha \beta$ s-spel wat buite die konteks van die banket sinneloos sou wees; die teenwoordige, dramatiese tyd "nou" (reël 1); "ons verliefdes" verwys na die groep vriende "hier teenwoordig" (3); en die "skool van Bromios (= Dionusos)" wat die banket waar Dionusos sy "opvoeding" uitvoer, is; in fr. 4, die vermelding van die beurtsang om die tafel; en die eksplisiete lokalisering in "by hierdie feesmaal". Uit fr. 4 is dit ook duidelik dat die oorspronklike gedig ' $n$ afskeidsgedig aan 'n lid van die sumposion was, m.a.w. 'n spesifieke geleentheid is ter sprake.

In hierdie geval het ons ook iets meer. Die twee fragmente word uit dieselfde gedig deur Athenaios aangehaal (15.668e). Tussen die twee aanhalings, meld Athenaios dat Ulpianus, een van die "gaste" in sy eie werk, die Deipnosophistai ("Geleerde banketgangers"), nog 'n beker wyn bestel het en toe fr. 4 voorgedra het. Ons het dus te make met 'n "sekondêre" voordrag. Al is Athenaios se verhaal denkbeeldig, dui dit steeds op die voordrag van simpotiese elegieë in sy eie tyd (c. $200 \mathrm{nC}$ )-soos ook sy eie werk, een van ons hoofbronne vir getuienis en tekste van die Griekse liriese, jambiese en elegiese poësie, bewys.

In frr. 3 en 4 meng letterlike met figuurlike banketelemente in 'n bewuste woordspel wat kenmerkend is van die nuwe intellektuele atmosfeer van laat-5e eeuse Griekeland. Die feesmaal, die sumposion, met al sy elemente word nou ook beeld, waar dit vroeër net letterlike beskrywing of milieu was. Iets hiervan is reeds in die elegieë van Ion van Chios te bespeur, waar hy die wyn van die sumposion personifieer (fr. 26 West, 1 Edmonds). In die verse van Dionusios is die spel van letterlike en figuurlike egter meer gesofistikeerd en volgehoue.

$\mathrm{Na}$ die letterlike, beskrywende besonderhede van 'n variante vorm van $\kappa o ́ \tau \tau \alpha \beta$ os in fr. 3, kom die feitelike of spesifieke doel van die gedig en sumposion, naamlik die vaarwel aan ' $n$ vriend wat op reis gaan, in figuurlike terme voor in fr. 4. Die "uitskink van himnes" in plaas van die letterlike heildronke met wyn, die "roeispane van die tong" in plaas van die werklike vervoermiddel, die "vaardigheid van die woord" wat "Phaiakiese [d.w.s. deskundige en ervare] roeiers na die roeibanke van die Muses stuur" in plaas van die skeepsvaartvaardigheid, is 
metaforiese inkleding vir "die liedere van afskeid wat ons ons vriend hier toesing moet hom veilig en vlot op sy reis voortdra."

Dieselfde verskynsel kom in frr. 1 en 5 West voor:

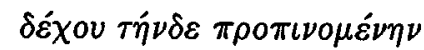

$\tau \grave{\eta} \nu \dot{\alpha} \pi^{\prime} \dot{\varepsilon} \mu o \hat{v} \pi \circ i \eta \sigma \nu^{\circ} \dot{\varepsilon} \gamma \grave{\omega} \delta^{\prime} \dot{\varepsilon} \pi L \delta \varepsilon^{\prime} \xi \iota \alpha \pi \tilde{\varepsilon} \mu \pi \omega$

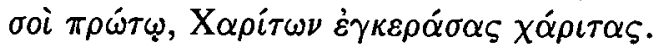

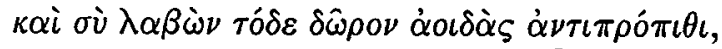

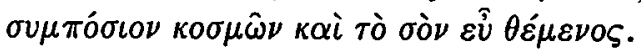

[O Theodoros,] ontvang hierdie heildronk van my poësie. Ek stuur van links na regs aan jou eerste gemengde gunste van die Grasies. Neem nou dié geskenk, en drink liedere aan my terug, en versier só die banket en verseker jou eie welsyn.

Die letterlike elemente (Theodoros, die aangee van die drinkbeker "van links na regs", die banket) dien as milieu vir die beeld: die digter sien sy liedere as 'n heildronk aan 'n vriend, en verwag 'n soortgelyke heildronk in ruil.

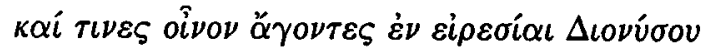

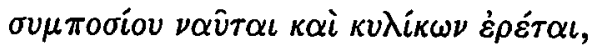

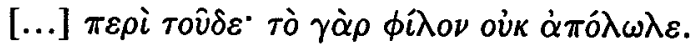

En sekere matrose van die feesmaal, die roeiers

van die bekers, bring wyn in Dionusos se geroei,

en ... híérvoor: want wat dierbaar is, is nie verlore ...

Hier keer die roei-metafoor van fr. 4 terug: Dionusos se aankoms word gesien in terme van ' $n$ bootreis; sy matrose of roeiers, so leer ons van Athenaios (10.443c), is Besopenheid, Raserny en Dronkgeweld. 'n Mens dink ook hier aan die uitbeelding op die Exekias-drinkbeker (Arias 1962: plaat XVI), waar Dionusos rustig in 'n boot vaar nadat hy die seerowers wat hom probeer oorval het, in dolfyne verander het (vgl. die Homeriese Himne aan Dionusos).

Hierdie proses waarin die letterlike elemente van die sumposion tot figuurlike of beeldende element in die gedig word, het 'n belangrike implikasie vir die bepaling van die gedig se geleentheid. As die elemente van die sumposion, en die sumposion self, beeld word, volg dit dat die geleentheid ook figuurlik word en daarna 'n literêre konvensie. 'n Soortgelyke proses kan teruggevind word in die teenwoordigheid van die lier in liriese poësie: eers werklike begeleidende instrument, later beeld van die liriek, uiteindelik blote literêre konvensie.

Die elegieë van Dionusios gee ons dus voorbeelde in die bestaande Griekse poësie van 'n oorgangsfase tussen letterlike referensie en beeldende funksie wat betref die banketelemente in die elegie. Die geleentheidsgedig verloor dan sy 
"letterlikheid", sy direkte verbinding met 'n werklike geleentheid, maar wen weer aan "figuurlikheid", aan beelding wat bo enige bepaalde geleentheid uitstyg. Bewustheid van hierdie proses is noodsaaklik vir die korrekte interpretasie van die betrokke poësie.

\section{$6 \cdot$ Euenos van Paros}

Van Euenos van Paros (c. $470-c .399 v C$ ) is 'n elegie behoue waarin die matigheid van die sumposion die hoofmotief is:

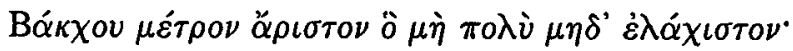

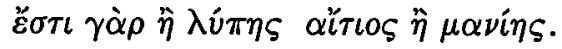

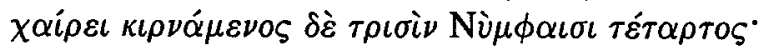

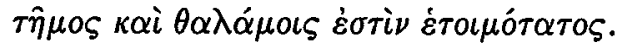

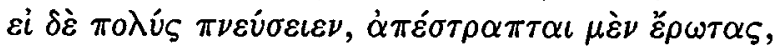

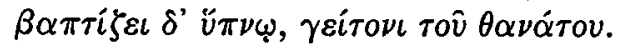

Die beste maat van Bakchos is nóg te veel nóg te min, want hy is die oorsaak van pyn of inspirasie.

Hy's bly as hy as vierde met drie nimfe gemeng is;

dan is hy ook vir die slaapkamer die mees geskik.

Maar as hy te veel uitadem, draai hy van sy liefdes weg, en doop ons in 'n slaap, buurman van die dood.

(fr. 2 West, Edmonds)

Die ideaal van matigheid in die sumposion is duidelik. Selfs die resep van wyn en water word gegee: een deel wyn (Bakchos self) met drie dele water (drie nimfe), dit wil sê $25 \%$ wyn, $75 \%$ water (r.3). Daar was sterker mengsels, maar die digter wil hier 'n balans stel: matigheid in die hoeveelheid wat gedrink word (r.1), én in die verhouding van wyn tot water in die mengsel. Die didaktiese inslag word gefokus op digterlike inspirasie (r.2) en seksuele vermoë (rr. 4-6), dit wil sê op een van die hoofaktiwiteite tydens die sumposion (poësie en sang) en een van die hoofaktiwiteit ná die sumposion (gedurende of na afloop van die $\kappa \hat{\omega} \mu \circ \varsigma$ ). 'n Treffende beeld sluit die fragment: slaap word as die "buurman van die dood" gesien. Die effek kom van die gedagte dat die slaap langs die dood woon, maar ook uit die laaste woord van die fragment: die dood. Die kortstondigheid van die lewe is 'n gereelde tema in simpotiese poësie, maar meer: Dionusos was die god van die kontinuerende, hergebore lewe, veral van die herlewende natuur na die winter. Sy besondere plante was die klimop en die wingerd wat albei in die vroeë lente hulle lewens- en groeikrag vertoon (Kerenyi 1976:52 e.v.). Die sumposion tot eer van Dionusos word dan eintlik 'n verklaring of manifes van hierdie faset van die lewe en die natuurwat die Grieke $\zeta \omega{ }^{\prime}$ noem. Dit is 'n protes teen sterflikheid, teen die dood. 


\section{Kritias van Athene}

Kritias van Athene (c.460-403), oligargiese politikus, filosoof, redenaar, wetmaker, soldaat, afstammeling van Solon, fluitspeler, prosaïs en digter, uiteindelik gehate despoot, teoretiseer oor die sumposion in vers en prosa. In fr. B2 West, 1 Edmonds gee hy 'n lys van die "spesialiteite" van verskeie streke en stede. Van Sicilië skryf hy:

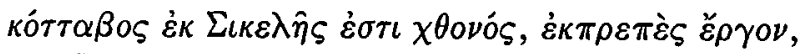

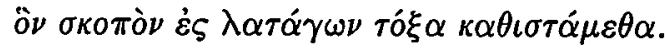

Die kottabos kom uit Siciliaanse bodem, 'n uitsoekding, wat ons as teiken vir die pyle van wyndruppels opstel.

(reëls 1-2)

'n Mens merk die metaforiese beskrywing van die wyndruppels as "pyle." 'n Tweede fragment onder sy naam (fr. 6 West, 2 Edmonds) handel oor die Spartaanse en Atheense banketgebruike:

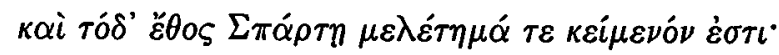

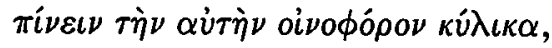

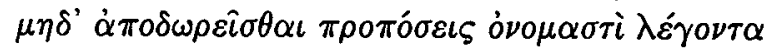
$\mu \eta \delta^{\prime} \dot{\varepsilon} \pi i \quad \delta \varepsilon \xi \iota \tau \varepsilon \rho \grave{\alpha} \nu \chi \varepsilon \hat{\imath} \rho \alpha \kappa \kappa^{\prime} \kappa \lambda \omega \theta i \dot{\alpha} \sigma o v$ [

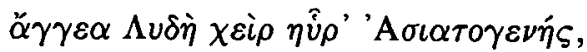

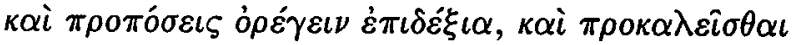

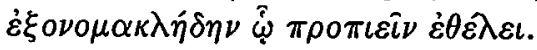

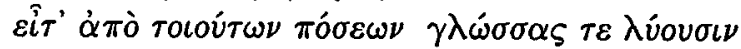

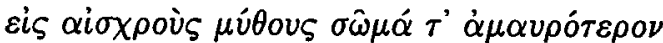

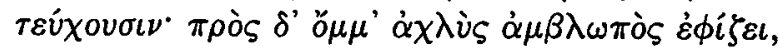

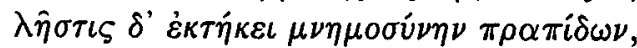

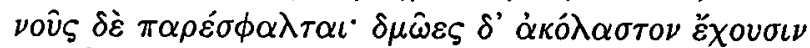

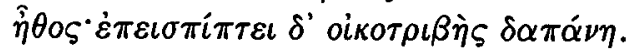

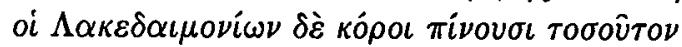
$\dddot{\omega} \sigma \tau \varepsilon \phi \rho \varepsilon \nu^{\prime} \varepsilon i \varsigma i \lambda \alpha \rho \dot{\alpha} \nu \dot{\alpha} \sigma \pi i \delta \alpha \pi \dot{\alpha} \nu \tau^{\prime} \dot{\alpha} \pi \dot{\alpha} \gamma \varepsilon \iota \nu$

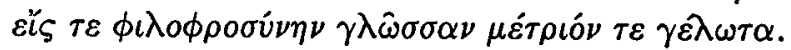

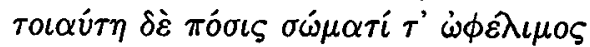

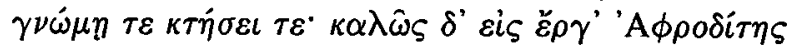

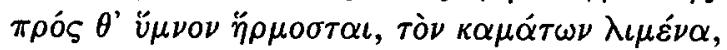

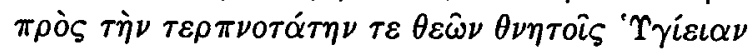

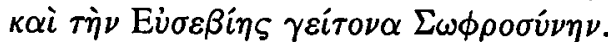

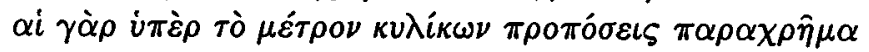

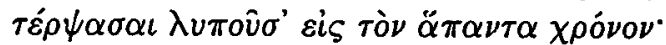
$\dot{\eta} \Lambda \alpha \kappa \varepsilon \delta \alpha \iota \mu o \nu i \omega \nu \delta \grave{\varepsilon} \delta i \alpha \iota \theta^{\prime} \dot{o} \mu \alpha \lambda \hat{\omega} \varsigma \delta \iota \dot{\alpha} \kappa \varepsilon \iota \tau \alpha \iota$, 


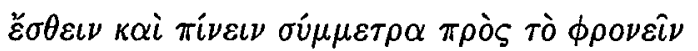

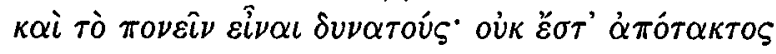

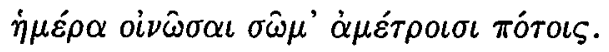

Ook dít is 'n gewoonte in Sparta, en 'n neergelegde gebruik:

om te drink uit dieselfde beker vol wyn,

en dit nie aan te gee as jy die heildronke by name instel, en nie na jou regterkant in ' $n$ kring om die groep

[die beker aan te gee nie ...

'n Lidiese hand, in Asië gebore, het kruike uitgevind,

asook die instel van heildronke na regs, en die uitroep

van die naam van die persoon op wie iemand wil drink.

Verder, na dergelike gedrink, raak die tonge los

vir vuil stories, en die liggaam word minder

sekuur; en op die oë gaan lê 'n donker mistigheid;

10

en vergetelheid smelt geheue van die verstand;

die brein skiet mis; die kelners se gedrag ontaard; en huisvernietigende onkoste sak neer.

Maar die Spartaanse jongmanne drink net genoeg om alle harte tot vrolike optimisme te bring,

en die tong tot lekker gesels en gematigde gelag.

Dié soort drink bevoordeel die liggaam,

verstand en eiendom. Dit pas die werk van Aphrodite goed, asook slaap, die hawe ná ons geswoeg,

en die aangenaamste godegawe vir die mens, Gesondheid,

en die buurman van Vroomheid, Selfbeheer.

Want bekers heildronke bo die maat bied onmiddellike genot maar pyn op die langtermyn;

die Spartaanse lewenswyse lê op eweredige vlak; om te eet en drink in verhouding tot die vermoë

om denke en optrede te behou; daar is nie 'n beskore dag om die liggaam dronk te maak met te veel doppe.

Die kontras tussen die meer beheersde Griekse (hier spesifiek Spartaanse) en die meer onbeheersde nie-Griekse, veral Skithiese, sumposia figureer in baie tekste (bv. Anakr. fr. 11 Page; Athen. 10.427ab). Hier is dit net duideliker en breedvoeriger uitgespel. Die fokus van die Griekse banket was intellektuele aktiwiteite soos die poësie en die gesprek, 'n uitvloeisel van die didaktiese funksie van die geleentheid. Kritias verwerp die oormatige gebruik van wyn met die gepaardgaande ongedissiplineerde en ongure taal, verlies van liggaamlike selfbeheersing, afname in helder visie en denke, en afbrekende effek op slawe en huishouding. Hierteenoor plaas hy die Spartaanse ideaal en gebruik van net genoeg wyninname om atmosfeer, intellek en genot te stimuleer, sodat liggaam, gees en optrede voordeel trek. Die behoud en deurgee van hierdie etiese norms van die adel tydens simposia is steeds in Kritias se 
tyd aktueel, en ons kan aanvaar dat die geleentheid waarvoor ook hierdie elegieë geskep is, die sumposion was. Ons weet dat Kritias ook in prosa oor die sumposiongebruike geskryf het. Athenaios (11.463e) verwys na Kritias se werk oor die Konstitusie van Sparta waarin hy die groottes van die drinkbekers van die inwoners van Chios, Thasos, Athene, Thessalië en elders vergelyk het.

Die proses van kennisvorming en -oordrag, van teorie en praktyk, is hier te bespeur in die nuwe inhoud en eksplisiete, "logiese" styl van die simpotiese elegie. Tradisie of gebruik is nie meer genoeg nie: daar moet eksplisiet opgeteken word waar dinge soos kóttabos en die sumposion self vandaan kom, hoe Griekse gewoontes van ander volkere s'n verskil. Kritias versinnebeeld in baie opsigte die nuwe soort Griekse literator wat onder andere oor die tradisionele sumposion in sy vers en prosa besin. En vir sy vers is die sumposion self nog die aangewese plek van kommunikasie.

\section{Anoniem}

'n Anonieme elegiese fragment, wat dalk uit die laat-5e of vroeg-4e eeue vC dateer, handel ook oor die sumposion:

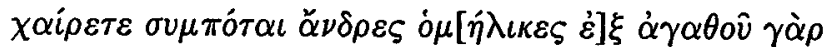

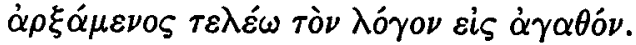

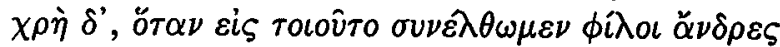

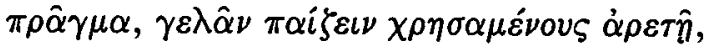

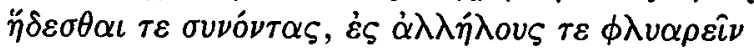

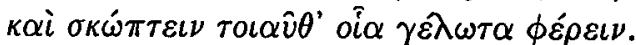

$\dot{\eta} \delta \grave{\varepsilon} \sigma \pi o v \delta \grave{\eta} \dot{\varepsilon} \pi \varepsilon ́ \sigma \theta \omega, \dot{\alpha} \kappa o u ́ \omega \mu \varepsilon \nu \tau \varepsilon \lambda \varepsilon \gamma \delta \dot{\nu} \tau \omega \nu$

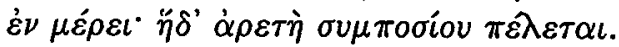

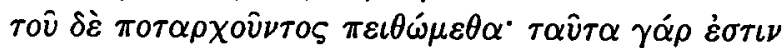

$\ddot{\varepsilon} \rho \gamma \gamma^{\prime} \dot{\alpha} \nu \delta \rho \hat{\omega} \nu \dot{\alpha} \gamma \alpha \theta \hat{\omega} \nu, \varepsilon \dot{\nu} \lambda \circ \gamma i \alpha \nu \tau \varepsilon \phi \dot{\varepsilon} \rho \varepsilon \iota \nu$.

Groete, ewe[oue] mede-feesgangers; want van die goeie

begin ek en eindig ek by die goeie woord.

Dit betaam ons, as ons as vriende hiérvoor byeengekom het,

om te lag en te "speel" ná ons die aretê beoefen het,

en samesyn te geniet, en om met mekaar onsin te gesels

en die spot te dryf met dit wat geskater voortbring.

En laat die erns volg, en laat ons luister na sprekers

in beurte; hierdie is die aretê van die feesmaal.

Laat ons na die seremoniemeester luister; want dít

is die gedrag van edelmanne: om lofprysing te bring.

$$
\text { (fr. adesp. eleg. } 27 \text { West) }
$$

Weer vind ons die eksplisiete besonderhede: die vergadering van aristokratiese manne van gemeenskaplike ouderdom (as ons met Schubart $\dot{o} \mu \dot{\eta} \lambda \iota \kappa \varepsilon \varsigma$ in die teks 
restoureer; die behoue $\dot{o} \mu$ - dui ten minste op een of ander gemeenskaplikheid in sosiale, ekonomiese en politieke belange); die verskeie aktiwiteite van die sumposion (die samesyn, saam drink, die ligte oomblikke van spot en skerts en "speel" met die jong kelners of aristokrate, en/of vroue-musikante en danseresse, die ernstige oomblikke van luister na digters, sangers of sprekers wat in beurte optree); en die funksie of doel van die sumposion (die nastreef van die "goeie", die aristokratiese

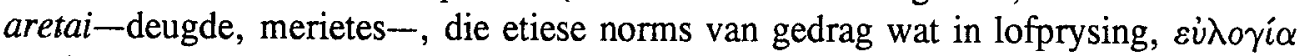
sy einddoel het).

\section{Antimachos van Kolophon}

Alhoewel geen van die oorblywende fragmente van Antimachos van Kolophon (5e$4 \mathrm{e}$ eeu v.C.) enige aanduiding van die wyse van kommunikasie bied nie, is heelwat uit die testimonia rondom sy elegiese poësie af te lei. Hy het byvoorbeeld in 'n poësiewedstryd tydens die fees ter ere van Lusandros, die sogenaamde Lusandreia, teen 'n sekere Nikeratos van Herakleia verloor (Plut. Lys. 18). Die $\dot{\alpha} \gamma \omega \dot{\omega} \nu$ in poësie was dus steeds 'n geleentheid waartydens gedigte vir die eerste keer voor 'n publiek of gehoor voorgedra is. Plutarchos vertel egter verder dat Antimachos in woede sy gedig vernietig het. Dit impliseer 'n geskrewe teks waarvan Antimachos hardop "afgelees" het of as geheuemiddel tydens sy geresiteerde voordrag by hom kon gehou het.

Hierdie afleiding, naamlik die bestaan en gebruik van 'n geskrewe teks van die gedig, word ondersteun deur ander uitsprake oor Antimachos se poësie. Dit het 'n bewuste, ongewone, geforseerde styl gehad (Dion. Halik. De veterum censura; Quint. 10.1.53: Proklos in Plat. Tim. 1.19e; die skolias by Kallim. fr. 398 Pfeiffer; Plut. Timol. 36), wat meer tipies is van "literêre", dit wil sê geskrewe, tekste wat vir lees bedoel is, as van mondelinge oordrag. Cicero se getuienis is insiggewend. Hy vertel (Brut. 51) dat Antimachos sy groot gedig, die Thebaïs, voor 'n gehoor voorgedra het, wat uiteindelik net uit Plato, wat sy poësie bewonder het (Plut. Lys. 18; Cic. Brut. 51), bestaan het. Dit sou nie 'n sumposion as geleentheid kon impliseer nie, maar eerder 'n semi-publieke voordrag voor genooide vriende en gaste.

Hierdie getuienis lei tot die gevolgtrekking dat die elegiese vers van Antimachos, ten minste vir 'n gedeelte, nie in die eerste plek in 'n simpotiese milieu voorgedra is nie, maar as geskrewe teks buite die sumposion in resitasievorm aan 'n semi-openbare gehoor, of as hardopgeleesde teks aan 'n enkeling (soos Plato) oorgedra is.

\section{Slot}

Die getuienis van die Griekse elegiese poësie wat tydens simposia voorgedra is, illustreer die ware wese en aktiwiteite van die Griekse simposium. Waar argeologiese materiaal soos die vasekuns en fondamente van geboue visuele maar 
stomme getuienis lewer, praat die oorblywende gedigte en gedigtefragmente direk met ons. Wat daaruit blyk, is die lewendige, skeppende en intellektuele milieu van die simposium as ruimte en geleentheid vir die genieting van die lewe, vir stimulerende geselskap, en vir die voordrag en aanhoor van poësie, ook die elegie. Deur al die tekste heen is daar die draad van ordelike en matige optrede en gedrag. Dit was ook die konteks waar die kwaliteit van die digkuns, van suiwer mondelinge improvisasie tot literêre woordkunswerk, bevorder is (Latacz 1990:235-254). Toe die simposium nie meer sentraal in die skepping, oordrag en behoud van die poësie gestaan het nie, het 'n nuwe publikasievorm, die geskrewe teks, van belang geword, met allerlei implikasies vir die vorm, inhoud en styl van die poësie, en die letterkunde as geheel. Waar die digter voorheen moes rondbeweeg om sy gedigte te kommunikeer, het sy gedigte nou in die vorm van tekste gesirkuleer (Vetta 1983:XI).

\section{BIBLIOGRAFIE}

Arias, P E 1962. A history of Greek vase painting. London: Thames \& Hudson.

Barkhuizen, J H, Henderson, W J \& Van Rooy, C A 1986. Kalliopê I: Griekse jambiese en elegiese poësie van Archilochos tot Theognis. Pretoria: Unisa.

Bielohlawek, K 1940. Gastmahls- und Symposionslehren bei griechischen Dichtern.

(Von Homer bis zur Theognissammlung und Kritias). WS 58:11-30.

Bowie, E L 1986. Early Greek elegy, symposium and public festival. JHS 106:1335.

Bowie, E Miles ludens? The problem of martial exhortation in early Greek elegy. In Murray 1990:221-229.

Edmonds, J M [1931] 1968. Greek Elegy and Iambus. 2 vols. Cambridge, Mass.: Harvard University Press.

Henderson, W J 1989. Die geleentheid van die vroeë Griekse elegie. Akroterion 34.2:171-184.

Höfer, O 1965. Prokles. In Roscher, W (ed), Lexikon der griechischen und römischen Mythologie 3.2:301-307. Hildesheim: Georg Olms.

Kerenyi, C 1976. Dionysos: Archetypal image of indestructible life. Vert. R. Manheim. London: Routledge.

Latacz, J 1990. Die Funktion des Symposions für die entstehende Griechische Literatur. In Kullmann, W \& Reichel, M (eds.), Der Übergang von der Mündlichkeit zur Literatur bei den Griechen, 227-264. ScriptOralia 30. Tübingen: Gunter Narr Verlag.

Lissarrague, F 1990. Around the krater: An aspect of banquet imagery. In Murray 1990:196-209.

Murray, O (ed) 1990. Sympotica: $A$ symposium on the symposion. Oxford: Clarendon Press.

Murray, O 1990a. The affair of the mysteries: Democracy and the drinking group. In Murray 1990:149-161. 
Pellizer, E 1990. Outlines of a morphology of sympotic entertainment. In Murray 1990:177-184.

Pötscher, W 1967. Herakles. Der kleine Pauly 2:1052. Stuttgart: Alfred Druckenmüller Verlag.

Rösler, W 1990. Mnemosyne in the symposion. In Murray 1990:230-237.

Schmitt-Pantel, P 1990. Sacrificial meal and symposion: Two models of civic institutions in the archaic city? In Murray 1990:14-33.

Stoll, H W 1965. Alkmena. In Roscher, W. (ed), Lexikon der griechischen und römischen Mythologie 1.1:246-248. Hildesheim: Georg Olms.

Vetta, M 1983. Poesia simposiale nella Grecia arcaica e classica. In idem, 1983a:XI-LX.

Vetta, M (ed) 1983a. Poesia e simposio nella Grecia antica. Bari: Universale Laterza.

Von der Mühll, P 1983. Il simposio greco. In Vetta 1983a:3-28 = Von der Mühll, P 1957. Das griechische Symposion. In idem, Xenophon: Das Gastmahl, 70109. Berlin = idem, 1976. Ausgewählte kleine Schriften, 483-505. Basel.

West, M L 1972. Iambi et elegi Graeci ante Alexandrum cantati. 2 vols. Oxford: Clarendon Press.

West, M L 1990. The Anacreontea. In Murray 1990:272-276. 